УДК 553.3/4.078 (571.66)

\title{
МЕТАЛЛОГЕНИЯ КАМЧАТСКОГО СРЕДИННОГО МАССИВА
}

\author{
Степанов В. А., Кунгурова В. Е., Койдан И. А. \\ ФГБУН Научно-исследовательский геотехнологический иентр ДВО РАН, г. Петропавловск- \\ Камчатский \\ E-mail: vitstepanov@yandex.ru
}

\begin{abstract}
Приведена характеристика рудоносности трех этапов отраженной активизации Камчатского срединного массива - позднемелового, эоценового и миоценового. В первый этап было сформировано золотое оруденение золото-кварцевой и золото-сульфидно-кварцевой формации, во второй - сульфидное платиноидно-медно-никелевое, в третий - золотомедно-молибденпорфировое. Показана связь золотого, сульфидного платиноидно-медно-никелевого и золотомедно-молибден-порфирового оруденения с определенными магматическими комплексами пород - кольским, дукукским и лавкинским. Отмечена добыча в пределах массива никеля, меди из месторождения Шануч и золота из россыпей.
\end{abstract}

Ключевые слова: металлогения, отраженная активизация, рудная формация, месторождение, проявление, россыпь.

DOI: 10.34078/1814-0998-2020-4-39-54

\section{ВВЕДЕНИЕ}

Камчатский срединный массив (КСМ) выделяется на фоне окружающих его вулканических поясов не только геологическим строением, но и рудоносностью. В целом для Камчатки наиболее типично вулканогенное золото-серебряное и телетермальное ртутное оруденение, а для северного фланга полуострова - россыпи платины (Степанов, 2008). Для срединного массива характерны другие типы рудных и россыпных месторождений, из которых наиболее известны сульфидное платинометалльное медно-никелевое месторождение Шануч, а также золото-кварцевые, золотомедно-молибден-порфировые проявления и россыпи золота. Эксплуатировались месторождение Шануч и россыпи золота. На месторождении добыто начиная с 2006 г. около 40 тыс. т никеля и 4.0 тыс. т меди, из россыпей извлечены первые сотни килограммов золота. Поскольку в полном объеме металлогения Камчатского срединного массива ранее не рассматривалась, в предлагаемой статье изложены основные особенности его геологического строения и рудоносности.

\section{ГЕОЛОГИЧЕСКОЕ СТРОЕНИЕ МАССИВА}

Камчатский срединный массив расположен в южной части Камчатского полуострова. Он представляет собой плитообразное тело, вытянутое в

(C) Степанов В. А., Кунгурова В. Е., Койдан И. А., меридиональном направлении на 260 км при ширине около 50-60 км. Это крупный выступ протерозойских метаморфических пород, местами перекрытых чехлом мезозойских терригенных и вулканогенно-осадочных образований. По форме срединный массив напоминает крупную блокпластину, вытянутую в меридиональном направлении и ограниченную с востока Шаромским, а с запада Воровским региональными разломами. Северным ограничением массива служит зона разлома субширотного направления, а южным северо-западного (рис. 1).

КСМ полностью отвечает критериям срединного массива в понимании А. Л. Яншина (Яншин, 1965), А. Д. Щеглова (Щеглов, 1971) и других исследователей. Камчатский срединный массив отмечался в ряде работ как Срединный Камчатский массив, Срединный Камчатский выступ, Центрально-Камчатский кристаллический массив или Срединно-Камчатский горстантиклинорий (Виноградов, Григорьев, 1994; Полетаев, 1999; Корякско-Камчатский..., 2002; Некрасов, 2003). В работе А. И. Ханчука доказывается двухэтажное строение массива. Нижний этаж сложен диафторированными кианитовыми, кордиеритовыми, кордиерит-гиперстеновыми гнейсами и плагиогнейсами со сложной слоистой структурой. На них почти горизонтально залегает прогрессивно метаморфизованный комплекс терригенно-вулканогенных отложений, отнесенный к малкинской серии палеозоя. Это позволило рассматривать Камчатский кристаллический массив как срединный (Ханчук, 1983). 


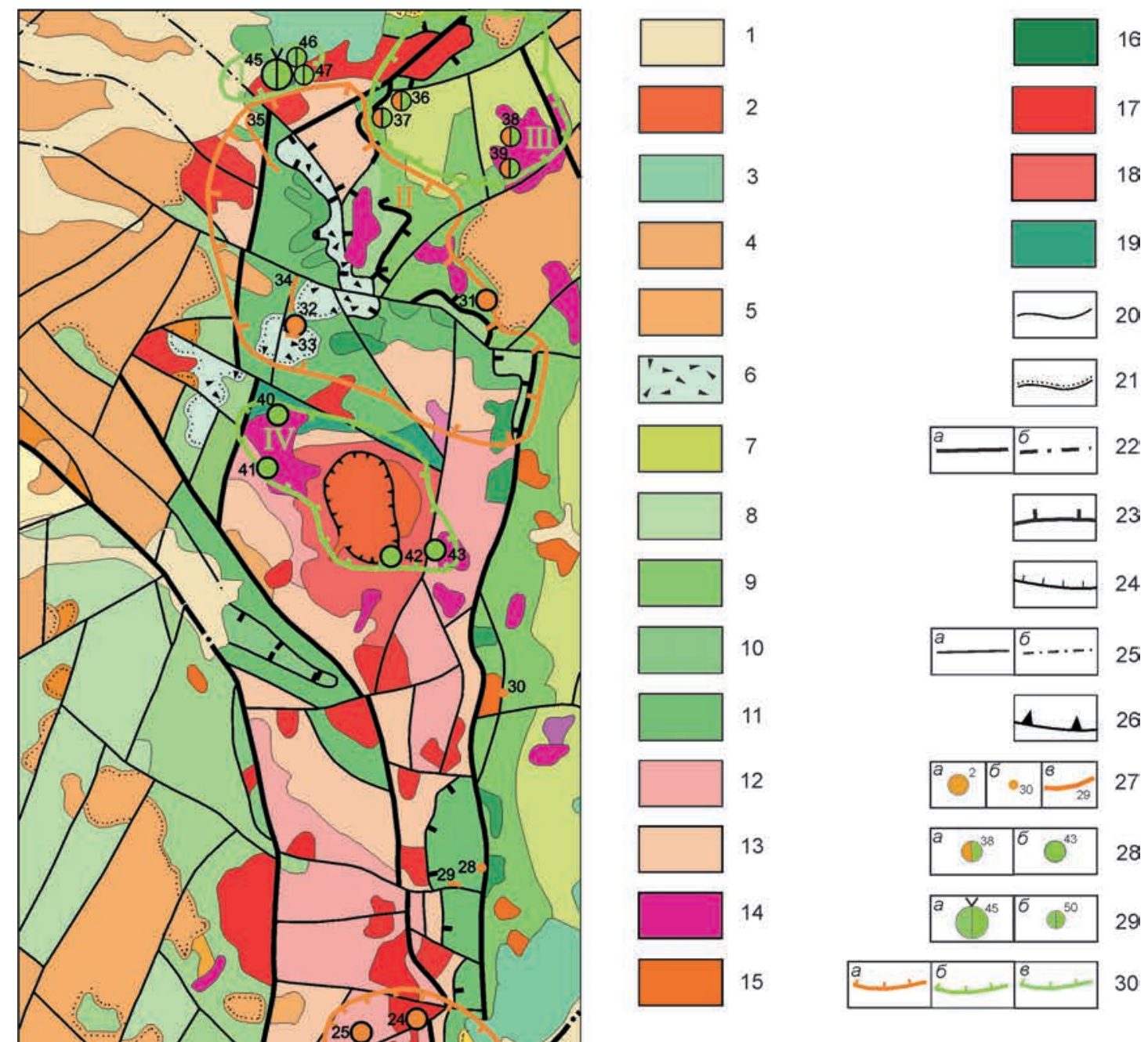

Puc. 1. Схема рудоносности Камчатского срединного массива по: (Карта..., 1999) с обобщениями и дополнениями авторов: 1 - рыхлые четвертичные аллювиальные, болотные, ледниковые, гляциофлювиальные отложения; 2 - хангарский четвертичный андезидацитовый вулканический комплекс (ВК); 3 - четвертичные вулканиты андезибазальтового состава; 4 - осадочные палеогеннеогеновые толщи; 5 - черепановский нижнепалеогеновый дацит-андезитовый ВК; 6 - верхнепалеогеновые тектоно-гравитационные микститы; 7 - кирганикская свита: туфы трахибазальтов, базальтов, андезибазальтов верхнего мела - нижнего палеоцена; 8-10 - верхнемеловые комплексы и свиты: 8 - кунунская, хозгонская свиты: алевролиты, аргиллиты, песчаники, аспидные сланцы; 9 - ирунейский базальтовый ВК; 10 - алисторский пикрит-базальтовый ВК; 11 - хейванская, химкинская свиты: метапесчаники и метаалевриты, графитовые филлиты, альбит-хлоритовые, эпидот-хлорит-актинолитовые сланцы нижнего - верхнего мела; 12, 13 - метаморфические серии верхнего протерозоя: 12 - камчатская: высокоглиноземистые кристаллические сланцы, микрогнейсы; 13 - колпаковская: амфиболовые плагиогнейсы, слюдяные плагиогнейсы; 14-18 - плутонические ком- 
плексы: 14 - лавкинский гранодиоритовый (миоцен), 15 - дукукский габбро-норит-кортландитовый (эоцен), 16 - левоандриановский дунит-клинопироксенит-монцонитовый (верхний мел - палеоцен), 17 кольский плагиогранит-гранодиоритовый (верхний мел), 18 - крутогоровский гнейсо-плагиогранитовый (нижний мел); 19 - андриановский метагаббровый (нижний палеозой); 20, 21 - геологические границы: 20 - между разновозрастными образованиями, 21 - несогласного залегания; 22-25 - разрывные тектонические нарушения: 22 - главные, выходящие на поверхность (a), скрытые под вышележащими образованиями (б), 23 - главные надвиги, 24 - второстепенные надвиги, 25 - второстепенные разломы, выходящие на поверхность (a), прочие разломы (б); 26 - кальдера вулкана Хангар; 27 - проявления $(a)$, пункты минерализации (б) золото-кварцевой и золотосульфидно-кварцевой формации и их номера; россыпи золота (в) и их номера; 28 - проявления $(a)$, пункты минерализации (б) золото-медно-молибден-порфировой формации и их номера; 29 - месторождение $(a)$, проявления (б) сульфидной медно-никелевой формация и их номера; 30 - границы рудных узлов с оруденением следующих формаций: $a$ - золото-кварцевой и золотосульфидно-кварцевой (II - Крутогоровский, V - Юртиный, VII - Порожисто-Гольцовский), б золото-медно-молибден-порфировой (III - Хим-Кирганикский; IV - Крутогоровско-Андриановский), в сульфидной медно-никелевой (I - Шанучский, VI - Дукукский); номера проявлений (П), пунктов минерализации (ПМ) и россыпей (Р): 1 - Гранитное (П), 2 - Утинское (П), 3 - Ближняя Гольцовка (ПМ), 4 - Дальняя Гольцовка (П), 5 - Утуй (П), 6 - Дальняя Гольцовка (Р), 7 - Средняя Гольцовка (Р), 8 - Ближняя Гольцовка $(\mathrm{P}), 9$ - Камешковая (Р), 10 - р. Утиная (Р), 11 - р. Утуй (Р), 12 - руч. Ивашка (Р), 13 - Куполонок (Р), 14 Юбилейный (Р), 15 - Ажица (Р), 16 - Дождливое (П), 17 - Восточное (П), 18 - Нижний (П), 19 - руч. Золотой (Р), 20 - Шишино-Чимстина (ПМ), 21 - Шишино-Чимстина (Р), 22 - Экополц (Р), 23 - Пеница (Р); 24 - Верхне-Юртиное (П), 25 - Вершинное (П), 26 - Юртиное (ПМ), 27 - Нижне-Юртиное (ПМ), 28 - Туманное (ПМ), 29 - верховья Озерной (Р), 30 - Широкий (ПМ), 31 - Дальнее (П), 32 - Майор (П), 33 - Майop (Р), 34 - Капитанская (Р), 35 - Химка (Р), 36 - Хим (П), 37 - Позднее (П), 38 - Кирганикское (П), 39 Туманное (П), 40 - Малахитовое (П), 41 - Квахона (ПМ), 42 - Правохейванское (П), 43 - Андриановское (П), 44 - Лев. Коль (ПМ), 45 - месторождение Шануч, 46 - Графитовое (П), 47 - Восточно-Геофизическое (П), 48 Тундровое (П), 49 - Квинум I, II (П), 50 - Ясное (П), 51 - Кортландитовое (П), 52 - Северное (П), 53 - Аннабергитовая Щель (П), 54 - Нижнемедвежье (П), 55 - Кувалорог (П), 56 - Оленье (П)

Fig. 1. Scheme of ore bearance of the Kamchatka middle massif after Map..., 1999, generalized and added by the authors: 1 - loose Quaternary alluvial, marsh, glacial, glaciofluvial deposits; 2 - Khangar Quaternary andesidacite volcanic complex (VC); 3 - Quaternary andesibasalt volcanites; 4 - sedimentary Paleogene-Neogene strata; 5 Cherepanovsky lower Paleogene dacite-andesite VC; 6 - Upper Paleogene tectonic-gravitational mixtites; 7 - Kirganik formation: tuffs of trachybasalts, basalts, andesibasalts of the upper Cretaceous - lower Paleocene; 8-10 upper Cretaceous complexes and suites: 8 - Kununsky, Khosgonsky suites: siltstones, mudstones, sandstones, slate shales; 9 - Iruneisky basalt VC; 10 - Alistorsky the picrite-basalt VC; 11 - Khevansky, Khimkinsky suites: metasandstones and metaaleurites; graphite phyllites, albite-chlorite, epidote-chlorite-actinolite schists of Lower Upper Cretaceous; 12, 13 - metamorphic series of Upper Proterozoic: 12 - Kamchatsky: high-alumina crystalline schists, microgneisses; 13 - Kolpakovsky: amphibole plagiogneisses, mica plagiogneiss; 14-18 - plutonic complexes: 14 - Lavkinsky granodiorite (Miocene), 15 - Dukuk gabbro-norite-cortlandite (Eocene), 16 - Levoandrianovsky dunite-clinopyroxenite-monzonite (Upper Cretaceous - Paleocene), 17 - Kola plagiogranite-granodiorite (Upper Cretaceous), 18 - Krutogorovsky gneiss-plagiogranite (Lower Cretaceous); 19 - andrianovsky metagabbrovy (lower Paleozoic); 20, 21 - geological boundaries: 20 - between heterochronous formations, 21 - of disconformity; 22-25 - tectonic ruptures: 22 - main ruptures opening onto the surface $(a)$, ruptures hidden under the overlying formations (б), 23 - main thrusts, 24 - minor thrusts, 25 - minor faults reaching the surface $(a)$, other faults (б); 26 - caldera of the Hangar volcano; 27 - occurrences $(a)$, mineralization points (б) of the goldquartz and gold-sulphide-quartz formations and their numbers; gold placers (b) and their numberы; 28 - occurrences $(a)$, mineralization points $(\sigma)$ of the gold-copper-molybdenum-porphyry formation and their numbers; 29 - deposit (a) occurrences (б) of the copper-nickel sulfide formation: and their numbers; 30 - boundaries of the ore nodes with mineralization of the following formations: $a$ - gold-quartz and gold-sulphide-quartz (II - Krutogorovsky, V Yurtiniy, VII - Porozhisto-Goltsovskiy), $\sigma$ - gold-copper-molybdenum-porphyry (III - Khim-Kurganinskiy, IV Krutogorovsko-Andrianovskiy), в - copper-nickel sulfide (I - Shanuch, VI - Dukuk); (P), of points of mineralization (PM) and placers (P): 1 - Granitnoye (P), 2 - Utinskoye (P), 3 - Blizhnyaya Golzovka (PM), 4 - Distant Golzovka (P), 5 - Utui (P), 6 - Distant Golzovka (R), 7 - the Average Goltsovka (R), 8 - Near Golzovka (R), 9 - Kameshkovaya (R), 10 - Utinaya River (R), 11 - Utui River (R), 12 - Ivashka Creek (R), 13 Kupolonok (R), 14 - Yubileyniy (R), 15 - Azhitsa (R); 16 - Dozhdlivoye (P), 17 - Vostochnoye (P), 18 Nizhniy (P), 19 - Zolotoy Creek (R), 20 - Shishino-Chimstina (PM), 21 - Shishino-Chimstina (R), 22 - Ecopolts (R), 23 - Penitsa (R), 24 - Verkhne-Yurtinoye (P), 25 - Vershinnoye (P), 26 - Yurtinoye (PM), 27 Nizhne-Yurtinoye (PM), 28 - Tumannoe (P), 29 - the Ozyornaya upper reaches (P), 30 - Shirokoye (PM), 31 Dalneye (P), 32 - Mayor (P), 33 - Mayor (R), 34 - Kapitanskaya (R), 35 - Khimka (R), 36 - Khim (P), 37 - Pozdneye (P), 38 - Kirganikskoye (P), 39 - Tumannoe (P), 40 - Malakhitovoye (P), 41 - Kvakhona (PM); 42 - Pravokheivanskoye (P), 43 - Andrianovskoye (P); 44 - Lev. Kol (PM), 45 - Shanuch deposit, 46 - Grafitovoye (P), 47 - Vostochno-Geofizicheskoye (P), 48 - Tundrovoye (P), 49 - Quinum I, II (П), 50 - Yasnoye (P), 51 - Kortlanditovoye (P), 52 - Severnoye (P), 53 - Annabergitovaya Shchel (P), 54 - Nizhnemedvezhye (P), 55 - Kuvalorog (P), 56 - Olenye (P) 
О. Б. Селянгин считает, что геологическое строение КСМ, положение интрузивов и происхождение исходной высокомагнезиальной бонинитоподобной магмы лучше согласуются с тектонической природой срединного массива в структуре эпигеосинклинального орогена (Cелянгин, 2009). Согласно классификации Нгуен Динь Ката (Нгуен Динь Кат, 1983), Камчатский срединный массив относится к дорифейским автохтонным массивам внутригеосинклинального типа с медно-никелевой и золотой минерагенической специализацией.

Массив имеет двухъярусное строение. Нижний структурный ярус представлен сложноскладчатыми породами колпаковской и камчатской метаморфических серий протерозоя. Колпаковская метаморфическая серия по составу делится на метаформации слюдяных и амфиболовых плагиогнейсов. Метаформация слюдяных плагиогнейсов представлена мигматизированными биотитовыми, гранат-биотитовыми, двуслюдяными, гранат-кианит-биотитовыми, гранаткианит-силлиманит-двуслюдяными плагиогнейсами, мигматитами, линзами будинированных амфиболитов. Мощность ее около 2000 м. Метаформация амфиболовых плагиогнейсов представлена амфиболовыми, гранат-силлиманитбиотитовыми, гранат-кианит-биотитовыми мигматизированными плагиогнейсами, амфиболитами, мигматитами. Мощность - 700 м. Камчатская метаморфическая серия тоже разделена на две формации - микрогнейсов и высокоглиноземистых кристаллических сланцев. Первая сложена гранат-биотитовыми, биотитовыми, двуслюдяными микрогнейсами, вторая - ставролитгранат-биотитовыми, мусковит-биотитовыми мигматизированными кристаллическими сланцами. Граница между метаформациями проводится по смене состава пород. Мощность образований метаформации микрогнейсов около 1600 , кристаллических сланцев - 1700 м.

Верхний структурный ярус сложен пологозалегающими преимущественно терригенными породами хейванской, химкинской и квахонской свит мезозойского возраста. В обрамлении массива находятся терригенные породы кихчикской серии и хозгонской свиты, вулканогенные и вулканогенно-осадочные породы ирунейской и кирганикской свит мезозойского возраста, а также осадочные, вулканогенно-осадочные и вулканические породы кайнозойского возраста. Древние метаморфические образования колпаковской и камчатской серий фундамента массива приурочены к центральной части массива, а терригенные, сланцевые и вулканогенно-осадочные толщи мелового и палеогенового возраста, слагающие его чехол, к периферии. В обрамлении массива развиты осадочные палеоген-неогеновые отложения.
Стратифицированные образования прорваны интрузиями андриановского метагаббрового комплекса палеозоя, крутогоровского плагиогранитового комплекса нижнего мела, кольского плагиогранит-гранодиоритового комплекса верхнего мела, левоандриановского дунит-клинопироксенит-монцонитового комплекса верхнего мела - палеоцена, базитов и гипербазитов дукукского комплекса эоцена, лавкинского гранодиоритового комплекса миоцена. Наиболее молодые риолиты и риодациты голоцена слагают Хангарское вулканическое сооружение.

В поле силы тяжести КСМ выделяется как область низких значений $\Delta \mathrm{g}$, которая по гравиметрическим ступеням субмеридионального простирания граничит с аномальными зонами положительного поля на востоке и западе. С севера КСМ отделен субширотной полосой горизонтальных градиентов поля силы тяжести от аномальной области отрицательного, сильно дифференцированного поля с дуговым рисунком изоаномал, типичного для структур ЦентральноКамчатского вулканического пояса. Большая часть горных пород, слагающих срединный массив, является немагнитной. На фоне немагнитных пород массива контрастными положительными аномалиями отмечаются интрузии среднего, основного и ультраосновного состава, а также вулканиты обрамления, эффузивы и пирокластические отложения вулкана Хангар в центральной части массива (Сидоров, Степанов, 2006).

\section{МЕТАЛЛОГЕНИЯ КСМ}

В пределах срединного массива выделены три этапа отраженной активизации, которые привели к формированию крупных интрузивных комплексов: кольского (позднемеловая эпоха), дукукского (палеоцен) и лавкинского (миоцен) и сопутствующего оруденения. В позднемеловой этап произошло образование оруденения золотокварцевой и золотосульфидно-кварцевой формации. Золотосодержащее медно-никелевое оруденение генетически связано с формированием в палеоцене основных-ультраосновных интрузий дукукского комплекса. В миоценовый этап возникли проявления золото-медно-молибденовой формации, связанные с субвулканическими интрузиями лавкинского комплекса.

Этап позднемеловой активизации. В позднемеловое время произошло внедрение гранитоидных интрузий кольского комплекса. Интрузии прорывают все докайнозойские образования, в более молодых не встречаются, а сами рвутся миоценовыми интрузиями лавкинского комплекca. K-Ar определения возраста пород комплекса на территории листа укладываются в интервале 57-89.5 млн лет. $\mathrm{Rb}-\mathrm{Sr}$ изохронные определе- 
ния соответствуют 66 млн лет (Боровцов и др., 2013)

С гранитоидами кольского комплекса, преимущественно со второй фазой, пространственно и генетически связаны зоны окварцевания и пиритизации, сопровождающиеся повышенной концентрацией молибдена, меди, цинка, свинца, олова, урана, золота, серебра, а также оруденение малосульфидной золото-кварцевой формации. Проявления и точки минерализации золотокварцевой, золотосульфидно-кварцевой формации, а также россыпи золота расположены на площади трех узлов - Крутогоровского, Юртинского и Порожисто-Гольцовского.

Крутогоровский узел находится на северном фланге КСМ (Сляднев, Шаповаленко, 2007). Он сложен главным образом терригенными, нередко черносланцевыми толщами мелового возраста, прорванными интрузиями плагиогранитгранодиоритового состава кольского комплекса верхнего мела. В его пределах известны проявления золота Дальнее и Майор, а также россыпи золота по р. Капитанская, руч. Майор и р. Химка.

Проявление Дальнее расположено в восточной части узла. В кремнистых породах и филлитах верхнего мела, прорванных субвулканическими телами диорит-порфиритов, находится серия кварцевых и кварц-карбонатных жил. Их мощность в раздувах достигает 1.5 м, протяженность до первых сотен метров. Содержание золота от 0.8 до 4.8 г/т, серебра до 1.5 г/т. Зона служит источником непромышленной россыпи по руч. Ветвистый и Дальний. Пробность золота в россыпи $870 \%$.

Проявление Майор обнаружено в юго-западной части узла. Вмещающие породы представлены филлитами хейванской свиты, прорванными телами ультрабазитов левоандриановского комплекса. В них находятся пять золотоносных кварцевых жил мощностью 0.8-2.5 м, прослеженных до 700 м. В одной из жил установлено содержание золота до 0.8 г/т, серебра до 92.4 г/т. В гидротермально измененных ультрабазитах содержание золота достигает 4 г/т, а в делювиальных обломках филлитов 10 г/т (Сляднев, Шаповаленко, 2007).

Poccbnu. Определенный интерес представляют россыпи р. Капитанская и руч. Майор. Россыпь р. Капитанская приурочена к пойме и первой надпойменной террасе нижней части долины. Золото в подавляющем большинстве мелкое и средней крупности. Его пробность составляет $801 \%$. Среднее содержание золота 252 мг/м³. Запасы по категории $\mathrm{C}_{1}$ составляют 37.5 кг золота. Забалансовая часть россыпи расположена в средней части долины. Размер золотин 0.15-0.25 мм. Забалансовые запасы составляют 419 кг, прогнозные ресурсы - 200 кг (Боровцов и др., 2013).
Россыпь руч. Майор приурочена к пойме и первой надпойменной террасе ручья. Золото мелкое и очень мелкое. Его пробность 804\%о. Запасы 30лота составляют 28 кг при среднем содержании

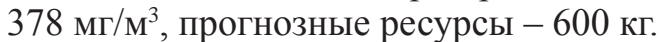

Юртинский рудный узел располагается на юго-восточной окраине Камчатского срединного массива. В геологическом строении узла принимают участие, главным образом, кристаллические сланцы колпаковской и камчатской серий, а также терригенные породы хейванской свиты мелового возраста. Стратифицированные образования прорваны крупной трещинной интрузией гранитов и гранодиоритов кольского комплекса верхнего мела, вытянутой в меридиональном направлении конформно простиранию срединного массива (Боровцов и др., 2016).

В пределах узла преобладает оруденение золото-кварцевой (проявления Вершинное, Верхне-Юртиное, Восточное и Нижнее) и золотосульфидно-кварцевой (Дождливое) формации, имеются россыпи золота. Золотое оруденение представлено кварцевыми, кварцкарбонатными жилами и линзами (проявления Верхне-Юртиное, Вершинное), а также зонами окварцевания и сульфидизации (рудопроявления Дождливое, Восточное и Нижнее). Вмещающими породами чаще всего служат граниты, гранодиориты и диориты, реже метаморфиты колпаковской серии, филлиты хейванской свиты. Вмещающие породы подвергнуты метасоматическому окварцеванию, аргиллизации и пиритизации.

Рудные минералы представлены, главным образом, пиритом, арсенопиритом, галенитом, халькопиритом, сфалеритом и самородным золотом. Реже встречаются шеелит, молибденит, канфильдит, прустит и пираргирит. Количество рудных минералов обычно не превышает $1-5 \%$. Исключение представляет рудопроявление Дождливое с более высоким содержанием сульфидов свинца, мышьяка и цинка. Содержания золота в большинстве рудопроявлений достигают первых, реже десятков граммов на тонну, серебра примерно в тех же количествах. На проявлении Дождливое руды обладают относительно высоким (51.5-2408.9 г/т) содержанием серебра. Для этого же проявления характерны повышенные содержания свинца (до 3.6\%), цинка (до 0.24\%) и мышьяка (до $1 \%$ ). По основным характеристикам большинство проявлений относятся к малосульфидной золото-кварцевой формации, а проявление Дождливое к золотосульфидно-кварцевой. Наиболее перспективны для постановки детальных поисковых работ проявления Дождливое золотосульфидно-кварцевой формации и Восточное золото-кварцевой. 
Небольшие непромышленные россыпи золота известны в долинах руч. Эполкоц и Золотой. Золото мелкое, хорошо окатанное, лепешковидной

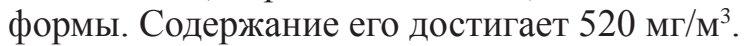

Порожисто-Гольцовский рудный узел расположен на южной оконечности Камчатского срединного массива (Сляднев, Шаповаленко, 2007). Узел приурочен к пересечению крупных разломов северо-восточной и северо-западной ориентировки, определяющих конфигурацию южного окончания срединного массива. На большей части узла развиты терригенные породы хозгонской, кихчикской и хейванской свит мелового возраста. Терригенные породы прорваны небольшими интрузиями кольского плагиогранит-гранодиоритового комплекса верхнего мела, а также дайками гранит-порфиров, лампрофиров, диоритов и дацитов.

В пределах узла установлены проявления золото-кварцевой (Утуй, Гранитное, Гольцовское) и золотосульфидно-кварцевой (Утинское) формаций, а также большое количество россыпей золота. Проявления представлены зонами окварцевания с кварцевыми и кварц-карбонатными жилами, реже сульфидизированными дайками гранит-порфиров. Вмещающие породы подвергнуты аргиллизации, окварцеванию и сульфидизации. Среди рудных минералов отмечаются пирит, арсенопирит, халькопирит, сфалерит, золото, шеелит и сульфосоли серебра. Количество рудных минералов не превышает 1-5\%, за исключением проявления Утинского, в рудах которого наблюдается повышенное содержание сульфидов (до 10-15\%). Содержания золота в целом не высоки и меняются от низких значений не более 1-5 г/т (проявления Утуй и Гольцовское) до 10-12 г/т (Гранитное и Утинское), в одной пробе проявления Гранитного содержание золота достигает 82.6 г/т (Карта..., 1999). Содержание серебра значительно выше, но не достигает значений, характерных для близповерхностного золото-серебряного оруденения. Из других компонентов отметим высокие содержания в рудах Утинского проявления свинца (до 5.98\%) и цинка (до $12.94 \%$ ). Большая часть рассмотренных проявлений отнесена к малосульфидной золотокварцевой формации, проявление Утинское - к золотосульфидно-кварцевой. В поисковом отношении наибольший интерес представляют проявления Утинское и Гранитное.

В пределах Порожисто-Гольцовского узла расположено десять россыпей золота. Запасы золота в них меняются от десятков (р. Ажица) до сотен килограммов (Утиная, Дальняя Гольцовка, Ближняя и Средняя Гольцовка) и до 1 т в россыпи p. Камешковая и руч. Половинчик. Добыча велась из россыпей Дальняя Гольцовка (добыто 80 кг), Средняя Гольцовка $(27.5$ кг) и Ближняя Гольцов- ка (14.5 кг). Золото в россыпях мелкое и средней крупности. Окатанность золотин средняя, иногда хорошая. Золото в большинстве россыпей умеренно высокопробное (815-848\%) и лишь в россыпи р. Утиная встречается электрум (пробность 581-664\%). Минералами-спутниками золота в россыпях являются большей частью магнетит и ильменит. В россыпях р. Утиная и Камешковая отмечается шеелит. Иногда встречаются сростки золотин с кварцем, на отдельных золотинах наблюдается лимонитовая «рубашка». В россыпи р. Ближняя Гольцовка обнаружены зерна платины, иногда со слабо заметной шестиугольной формой. Большинство россыпей образовано вследствие эрозии располагающихся в непосредственной близости проявлений золото-кварцевой формации. В отличие от них россыпь р. Утиная, в которой преобладает электрум, сформирована за счет проявления Утинского золотосульфиднокварцевой формации. Россыпи узла нуждаются в дальнейшем опоисковании.

Этап палеоценовой активизации. Наибольшее промышленное значение в пределах Камчатского срединного массива имеет сульфидное медно-никелевое оруденение, сформированное в палеоцене. Здесь разведано и эксплуатируется Шанучское медно-никелевое месторождение, имеются десятки перспективных проявлений, а также точки минерализации и ореолы рассеяния никеля и меди. Это позволило выделить Шанучский и Дукукский рудные районы, а также Колпаковский потенциальный рудный район (Трухин и др., 2008).

Шанучский рудный район расположен на северной окраине Камчатской никеленосной провинции. Площадь его составляет около 1400 км² $^{2}$. Он имеет коленообразную форму, вызванную сочетанием ограничивающих разломов меридионального и субширотного направлений. Никеленосным является дукукский габбро-нориткортландитовый плутонический комплекс. Он представлен небольшими штоками, дайками и пластовыми телами амфиболовых габбро, пироксенитов, перидотитов, горнблендитов, кортландитов, диоритов мощностью от нескольких до 200 м и протяженностью до 1200 м. Малые интрузии являются апофизами крупных массивов. В рассматриваемом рудном районе известны месторождение Шануч, проявления ВосточноГеофизическое и Графитовое.

Шанучское сульфидное медно-никелевое месторождение находится в западной части Шанучского рудного поля, на склоне г. Верхняя Тхонжа, служащей водоразделом между р. Ича и ее притоком р. Шануч (Трухин и др., 2009). Оно открыто в 1971 г., а в настоящее время находится в стадии эксплуатации. Площадь месторождения сложена кристаллическими сланцами и гнейса- 
ми камчатской серии. На флангах месторождения они перекрыты метатерригенными образованиями хейванской свиты. Метаморфические толщи прорваны интрузиями дорудного крутогоровского комплекса гнейсовидных плагиогранитов и гнейсогранитов, а также интрузиями кольского гранит-плагиогранитного комплекса.

Рудоносными являются малые интрузии, дайки и силлы амфиболовых, биотит-амфиболовых меладиоритов, габбро, пироксенитов, горнблендитов и кортландитов дукукского комплекса, возраст которого по данным абсолютного возраста оценивается как эоценовый (Степанов, Трухин, 2007). На месторождении наблюдается серия сближенных интрузий, вытянутых в субширотном направлении. Мощность отдельных интрузий от первых метров до 150-200 м. Падение их преимущественно в южных румбах под углами 45-70을 нередко встречаются участки вертикального или крутого наклона на север.

Месторождение Шануч представлено пучком субвертикально ориентированных рудных тел, сопряженных с небольшими интрузиями неправильной формы и дайками дукукского комплекса, размещение которых контролируется разрывными нарушениями. Наблюдается сложная жилообразная, штокообразная и линзовидная форма рудных тел, сложенных сульфидными медно-никелевыми рудами. Контуры рудных тел определялись по данным опробования.

На месторождении наиболее представительным и хорошо изученным является рудное тело 1 , имеющее в плане сложную серповидную форму, размерами $120 \times 50$ м (рис. 2). Оно прослежено на глубину около 320 м. Общая мощность рудного тела колеблется от 1.4 до 53.9 м. В вертикальном разрезе оно имеет трубообразную форму с неправильным эллипсовидным сечением. Падение его крутое, близкое к вертикальному. В целом рудное тело повторяет контур материнской интрузии мафит-ультрамафитового состава. В его краевых частях отмечаются ксенолиты измененных кристаллических сланцев с прожилковой и вкрапленной сульфидной минерализацией. Контакты интрузивных пород с вмещающими гранитогнейсами четкие, резкие, нередко тектонические. Сульфидная минерализация приурочена к разрывным нарушениям. Эти постмагматические структурные элементы являлись, очевидно, рудовмещающими и рудоконтролирующими каналами, по которым рудоносные расплавы и растворы двигались из магматического очага к участкам рудоотложения и отводились по системам трещин во вмещающие породы.

На основании минералогического картирования выделены следующие первичные руды: массивные, брекчиевидные, гнездово-вкрапленные и вкрапленные.
Maсcивные руды на 75-95\% состоят из сульфидов. Они содержат обломки вмещающих пород (меладиориты, амфиболовые габбро, пироксениты, гнейсовидные граниты, кристаллические сланцы) удлиненной или изометричной формы. Текстура руд массивная, структура - аллотриоморфнозернистая или распада твердого раствора.

Брекчиевидные руды состоят из обломков вмещающих пород, сцементированных сульфидным материалом. Текстура руд брекчиевая, брекчиевидная, реже пятнистая. Структура аллотриоморнозернистая, сидеронитовая, реже гипидиоморфнозернистая. Содержание сульфидных минералов достигает 40-80\%.

Гнездово-вкрапленные руды объединяют разности с прожилковыми, прожилково-вкрапленными и вкрапленно-прожилковыми текстурами. Структура руд аллотриоморфнозернистая, интерстициальная, петельчатая. Они содержат 10$30 \%$ сульфидов.

Вкрапленные pyдbl состоят из меладиоритов, габбро, кортландитов с рассеянной сульфидной минерализацией. Количество сульфидов - 3-10\%. Текстура руд вкрапленная, реже прожилково-вкрапленная; структура аллотриоморфнозернистая, интерстициальная.

Наблюдается зональное размещение отдельных типов руд как в поперечном разрезе рудного тела, так и по вертикали. Центральная часть рудного тела 1 обычно выполнена массивными рудами, образующими одиночные или сближенные жилы, мощностью от 0.2 до 3.0 м. Жилы окружены зонами бречиевидных либо гнездововкрапленных руд мощностью от 0.2 до 6.9 м. В периферической части рудного тела располагаются вкрапленные руды.

Среднее содержание полезных компонентов по рудному телу составляет, \%: никель -5.41 , медь -0.85 , кобальт -0.13 ; благородных металлов, г/т: золото -0.24 , палладий -0.40 , платина -0.13 . Выявлена наиболее тесная корреляционная связь между содержаниями никеля и кобальта (0.96; при $\mathrm{n}=292)$, несколько менее тесная между содержаниями никеля и меди (0.76), а также между медью и кобальтом (0.75). Отмечается устойчивая корреляционная связь палладия и золота с никелем, медью и кобальтом; у платины корреляционные связи с этими элементами отсутствуют.

По оптическим характеристикам в рудах месторождения Шануч установлен широкий спектр минералов. Самородные - золото, изоферроплатина, медь, железо, графит; сульфиды - халькопирит, моукохит, борнит, халькозин, ковеллин, пирротин, пентландит, пирит, линнеит, зигенит, маккинавит, виоларит, полидимит, грейгит, миллерит, годлевскит (?), хизлевудит (?), сфалерит, 


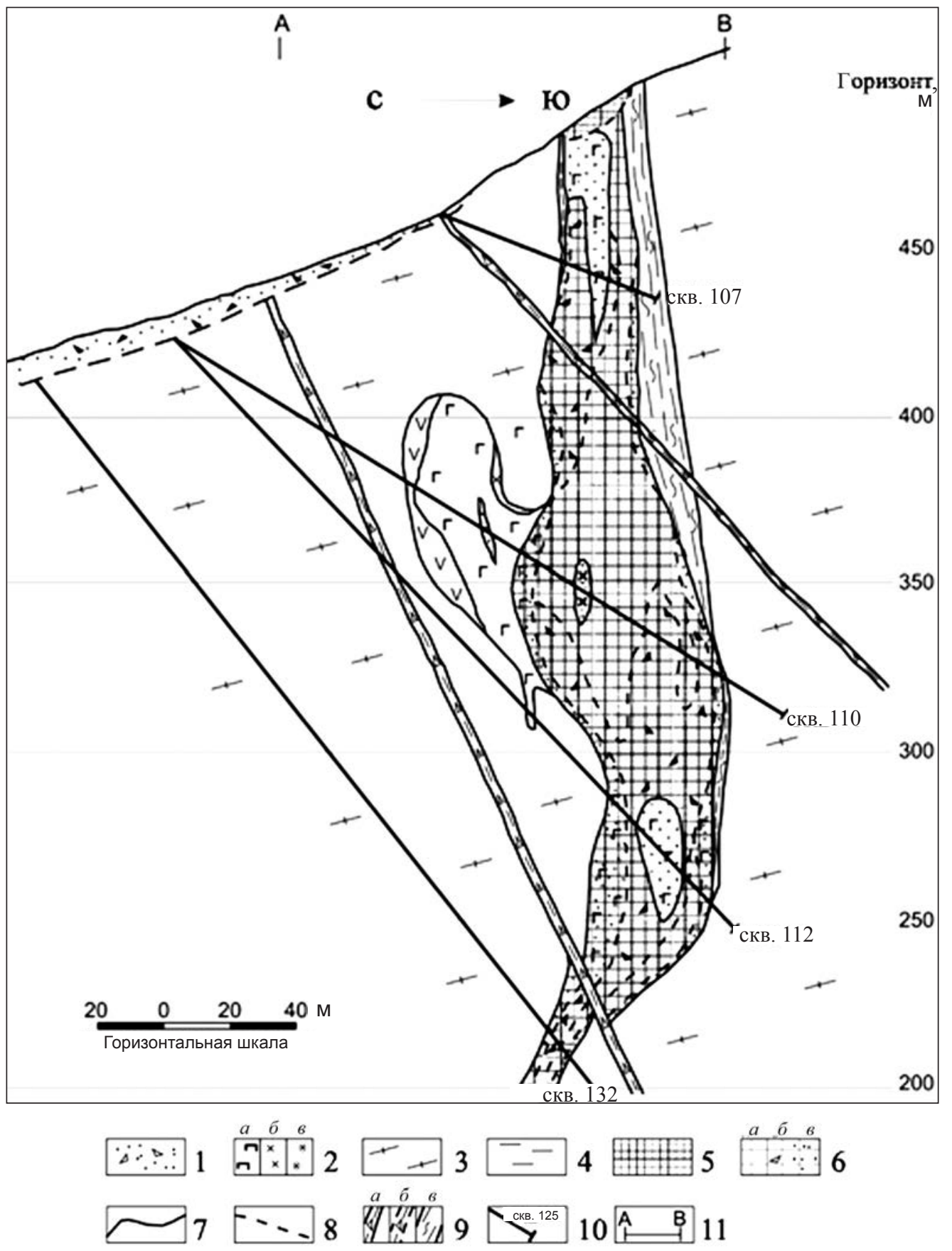

Puc. 2. Схематический разрез по рудному телу 1 месторождения Шануч (с использованием данных 3АО НПК «Геотехнология»): 1 - рыхлые четвертичные отложения; 2 - интрузии дукукского комплекса: амфиболовые габбро (a), биотит-амфиболовые меладиориты (б), гранатсодержащие мусковит-биотитовые диориты (в); 3 - крутогоровский гнейсово-плагиогранитовый комплекс: гнейсовидные плагиограниты, гнейсограниты, плагиограниты; 4 - камчатская метаморфическая серия: кристаллические сланцы гранат-ставролит-биотитового состава; 5 - окисленные руды; 6 - сульфидные медно-никелевые руды: массивные $(a)$, брекчиевидные, гнездововкрапленные (б), прожилково-вкрапленные и вкрапленные (в); 7 - геологические границы; 8 - границы между типами руд; 9 - зоны дробления: достоверные $(a)$, предполагаемые (б), зоны милонитизации (в); 10 - скважины, по которым отобраны образцы руд, их номера; 11 - линия разреза

Fig. 2. Schematic section of ore body 1 of the Shanuch Deposit (using data from Geotechnology Co.): 1 - loose Quaternary deposits; 2 - intrusions of the Dukuk complex: amphibole gabbro (a), biotite-amphibole meladiorites (б), garnet-containing muscovite-biotite diorites (b); 3 - Krutogorovskiy gneiss-plagiogranite complex: gneiss-like plagiogranites, gneissogranites, plagiogranites; 4 - Kamchatskaya metamorphic series: crystal shales of garnet-stavrolite-biotite composition; 5 - oxidized ores; 6 - copper-nickel sulfide ores: massive $(a)$, breccian, nest-impregnated (б), veined-impregnated and impregnated $(8) ; 7$ - geological boundaries; 8 - boundaries between ore types; 9 - crushing zones: reliable $(a)$, assumed (б), mylonitization zones $(8) ; 10$ - wells, from which ore samples were selected, their numbers; 11 - section line 
галенит, молибденит; арсениды - никелин, леллингит, раммельсбергит, саффролит, сперрилит; сульфоарсениды - герсдорфит, кобальтин, арсенопирит; антимониды - брейгауптит, ульманит; теллуриды и сульфотеллуриды - теллуровисмутит, мелонит, майченерит, мончеит, котульскит (?), меренскит (рис. 3). Из платиноидов наиболее распространен сперрилит, встречается ирарсит (Степанов и др., 2010).

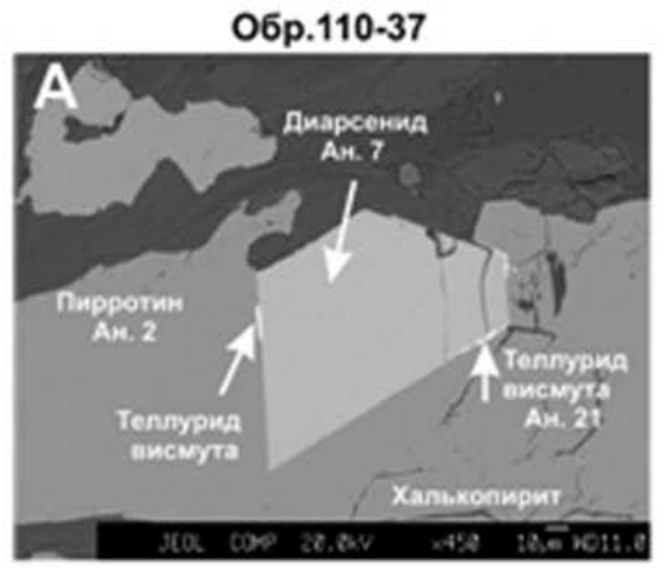

06p. 110-22

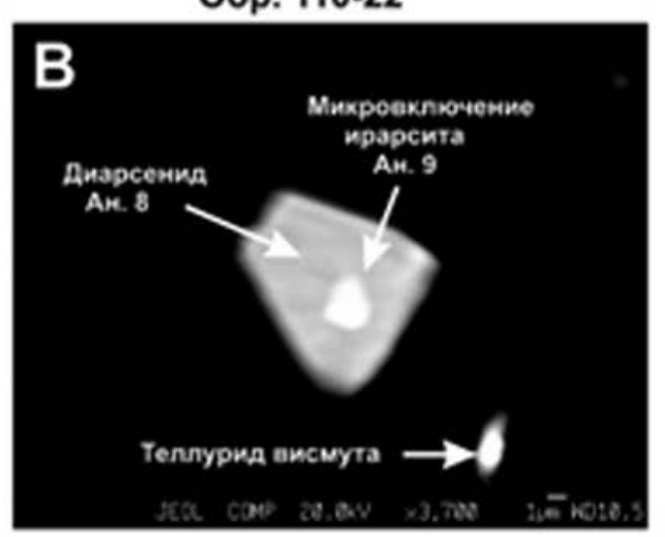

06p. $107-4$

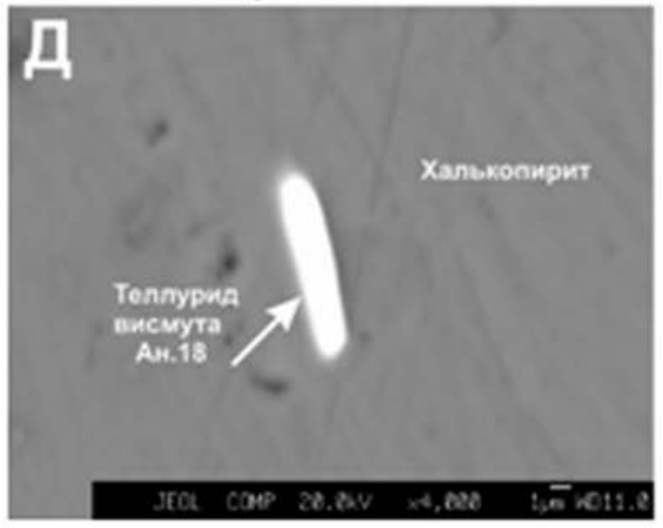

Для уточнения возраста никеленосных интрузий нами выполнены изотопные анализы отдельных минералов рудоносных интрузий месторождения Шануч и проявления ВосточноГеофизическое. Анализы произведены $\mathrm{Rb}-\mathrm{Sr}$ методом в центре изотопных исследований ВCEГЕИ на термоионизационном масс-спектрометре Triton (Германия). В результате анализа для месторождения Шануч получена изохрона -
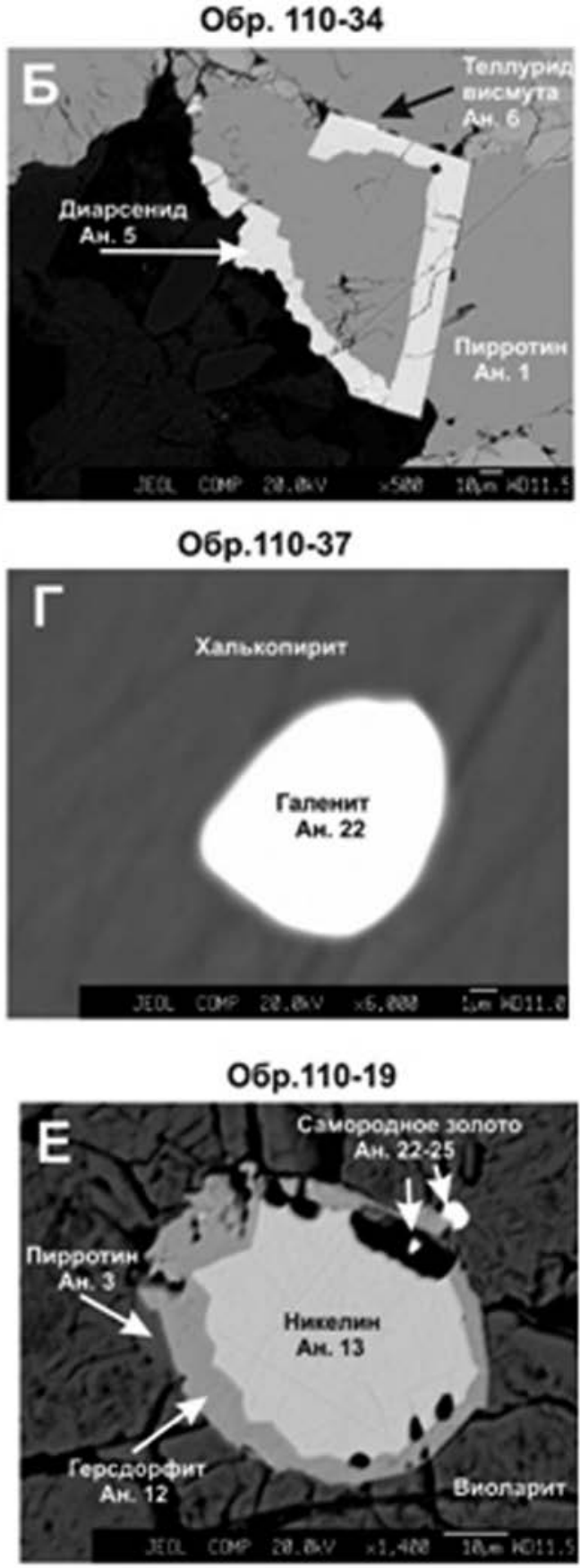

Puc. 3. Характерные взаимоотношения минералов в рудном теле 1 месторождения Шануч (рентгеноспектральный микроанализатор, в отраженных электронах): А - идиоморфный кристалл диарсенида (светлосерое - 5.5 мас.\% Со) на контакте моноклинного пирротина и халькопирита (серое) с породообразующими минералами (темно-серое); вдоль границы диарсенида наблюдаются микровключения теллуридов висмута и галенита (белое); Б - скелетный кристалл диарсенида (белое - 10 мас.\% Со) по границе зерен гексагонального (с отдельностью по 0001) пирротина (серое), пентландита (светло-серое) и породообразующих минералов 
(темно-серое); В - в пирротине (черное) идиоморфный кристалл диарсенида (серое - 14 мас.\% Со) с изометричным микровключением ирарсита; Г - каплевидное зерно галенита в халькопирите; Д - микрозерно теллурида висмута вытянутой формы в халькопирите; Е - каемочная структура замещения идиоморфного зерна никелина (светлосерое) герсдорфитом (серое - 1 мас.\% Со) среди виоларита (темно-серое), заместившего пентландит; по границам зерен и в пустотках выщелачивания (черное) наблюдаются микровключения самородного золота (белое)

Fig. 3. Characteristic relationships of minerals in ore body 1 of the Shanuch Deposit (X-ray spectral microanalyzer, in reflected electrons): A - idiomorphic diarsenide crystal (light grey $-5.5 \mathrm{wt} . \% \mathrm{Co}$ ) at the contact of monoclinic pyrrhotite and chalcopyrite (gray) with rock-forming minerals (dark gray); along the border of diarsenide microinclusions of bismuth and galena tellurides are observed (white); Б - skeletal diarsenide crystals (white - $10 \mathrm{wt} \%$ Co) along the border of grains of hexagonal (with a jointing on 0001) pyrrhotite (gray), pentlandite (light gray) and rock-forming minerals (dark gray); B - in pyrrhotite (black) an idiomorphic crystal of diarsenide (gray - 14 wt. \% Co) with isometric micro-inclusion of irarsite; $\Gamma$ - teardrop-shaped grain of galenite in chalcopyrite; $Д$ - elongated bismuth telluride micrograin in chalcopyrite; E - border structure of an idiomorphic grain of nickel (light gray) substituted with gersdorffite (gray -1 wt.\% Co) among violarite (dark gray), which replaced pentlandite; microinclusions of native gold (white) are observed along the grain boundaries and in the leaching voids (black)

49.2 \pm 2.7 млн лет, а для Восточно-Геофизического

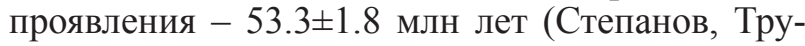
хин, 2007). Это свидетельствует о раннеэоценовом возрасте никеленосных интрузий Шанучского рудного района.

Дукукский рудный район расположен на южной окраине Камчатской никеленосной провинции. Ему соответствует южная относительно опущенная часть Камчатского срединного массива. Юго-западная часть района представлена преимущественно терригенными отложениями хейванской свиты мелового возраста. В северовосточной части района располагается Пымтинский выступ фундамента срединного массива. Среди интрузивных образований в юго-западной части района преобладают небольшие интрузии, дайки и силлы дукукского никеленосного комплекса эоцена. В северо-восточной части преобладают массивы гранитоидов кольского комплекса верхнего мела, а небольшие интрузии и дайки дукукского комплекса располагаются вдоль восточного края Пымтинского выступа.

Дукукский габбро-норит-кортландитовый плутонический комплекс является никеленосным, несущим сульфидную платиноидно-медноникелевую сингенетичную и эпигенетичную минерализацию. Интрузии комплекса представлены двумя типами. Первый - это крупные пластино- и лополитообразные тела площадью до 20 30 км$^{2}$ и мощностью более 1 км, второй - малые интрузии, силлы и дайки.

Для определения изотопного возраста Кувалорогской интрузии нами были отобраны мономинеральные фракции флогопита и сростков флогопита с амфиболом из кортландитов и флогопитовых горнблендитов. Эти пробы были проанализированы Rb-Sr методом в Центре изотопных исследований ВСЕГЕИ на девятиколлекторном масс-спектрометре Triton (Германия). B результате анализа получена изохрона с возрастом 55.2 2.2 млн лет. Это отвечает верхней части палеоцена на границе с эоценом.
В пределах Дукукского района находится ряд проявлений сульфидных медно-никелевых руд, точек минерализации и вторичных ореолов рассеяния никеля и меди. Они сосредоточены в двух никеленосных зонах - Квинум-Кувалорогской и Дукукско-Пеницкой.

Квинум-Кувалорогская никеленосная зона северо-западного простирания расположена в южной части рудного района. В пределах зоны выделены следующие типы медно-никелевого оруденения: расслоенные материнские интрузии с сингенетичным сульфидным оруденением (Кувалорогский массив с проявлениями Снежное, Нижнемедвежье, Перевальное, Кувалорог, Правокихчинское, Рассоха, Надежда); малые тела мафитультрамафитов (сателлиты материнских интрузий), слабо или недифференцированные с сингенетичным сульфидным оруденением (Северное, Озерное, Обвальное, Медвежий мыс, Оленье); дайкообразные тела ультрамафитов с богатым эпигенетическим сульфидным оруденением (проявления Аннабергитовая Щель, Коба). Наиболее перспективное проявление - Аннабергитовая Щель.

Медно-никелевое проявление Аннабергитовая Щель расположено в истоках руч. Гранатовый, притока р. Степанова. В геологическом строении района рудопроявления принимает участие северо-западный край крупного Кувалорогского интрузива дукукского плутонического комплекса эоценового возраста, образованного ультраосновными, основными и средними породами. Интрузия прорывает меловые сланцы хейванской свиты. Среди сланцев отмечаются небольшие интрузии эоценового дукукского комплекса и миоценовые дайки андезитов кимитинского комплекса. К северо-востоку от проявления расположена интрузия гранитоидов кольского комплекса (Кунгурова и др., 2014).

Медно-никелевые руды располагаются в южном борту распадка Аннабергитовая Щель. Рудное тело имеет в разрезе треугольную форму (рис. 4). 


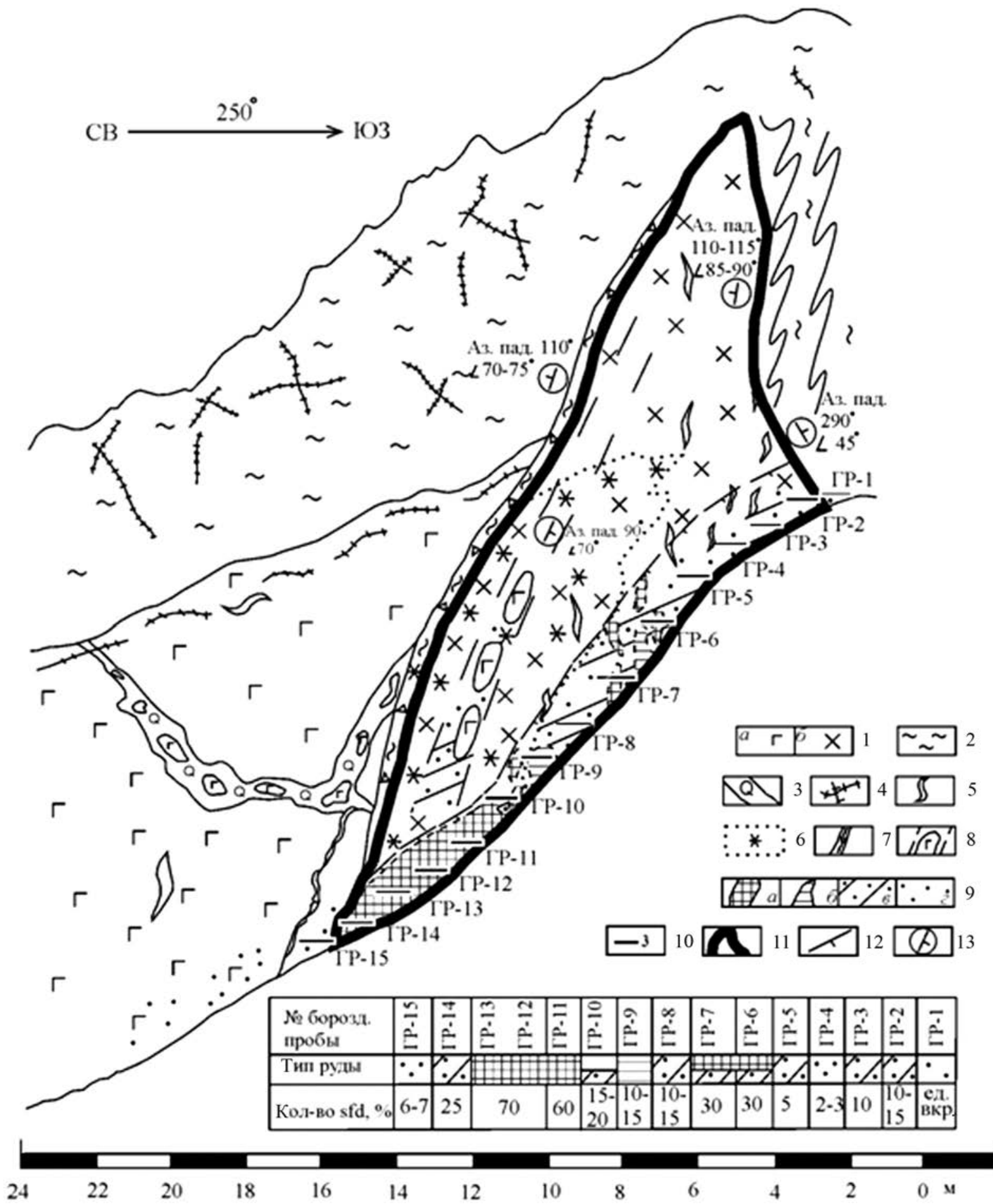

Puc. 4. Выход рудного тела в борту распадка Аннабергитовая Щель: 1 - дукукский интрузивный комплекс эоцена: $a$ - кортландиты, $\sigma$ - габбро-диориты, диориты; 2 - филлиты, метаалевролиты хейванской свиты нижнего мела; 3 - окварцевание; 4 - кварцевые прожилки; 5 - кварц-полевошпатовые прожилки с сульфидами; 6 - лимонитизация, хлоритизация; 7 - зона дробления, рассланцевания; 8 - ксенолиты кортландитов, 9 руды: $a$ - массивные, $\sigma$ - массивные, частично окисленные, 6 - прожилково-вкрапленные, гнездовые, 2 - вкрапленные; 10 - места отбора бороздовых проб; 11 - контур рудного тела; 12 - контур опробованной части рудного тела; 13 - элементы залегания пород

Fig. 4. Ore body outcrop in the Annabergitovaya Shchel cleavage side: 1 - Dukuk Eocene intrusive complex: $a-$ cortlandites, $\sigma$ - gabbro-diorites, diorites; 2 - phyllites, metaaleurolites of the Early Cretaceous Kheyvan suite; 3 - calcification; 4 - quartz veins; 5 - quartz-feldspar veins with sulfides; 6 - limonitization, chloritization; 7 - crushing zone; 8 - cortlandite xenoliths; 9 - ores: $a$-massive, $\sigma$ - massive, partially oxidized, $b$ - veinle-impregnated, nesting, 2 -impregnated; 10 - furrow sampling spots; 11 - ore body contour; 12 - contour of the ore body tested par; 13 - elements of rock bedding 
Его размеры следующие: измеренная длина по днищу распадка - 18 м, ориентировочная высота западного вертикального края - 11 м, вычисленная длина восточного края рудного тела -24 м. Тело отчетливо расширяется на глубину. Вмещающими породами служат сланцы хейванской свиты и частично горнблендиты, габбронориты, диориты и меланократовые диориты Аннабергитовой интрузии - сателлита Кувалорогского массива.

Рудное тело представлено интрузией среднего состава (меланократовые диориты, диориты с прожилками плагиогранитов) с наложенным сульфидным медно-никелевым оруденением. Структура руды массивная, прожилково-вкрапленная, гнездово-вкрапленная и вкрапленная. Она содержит будины и линзы пород основного и ультраосновного состава. В размещении разных типов руд наблюдается определенная зональность: в восточной части рудного тела располагаются преимущественно массивные и прожилкововкрапленные руды, сменяющиеся к западу и вверх по распадку гнездово-вкрапленными и вкрапленными. С поверхности рудное тело покрыто бурыми гидроксидами железа, а также зеленоватыми корочками аннабергита, встречаются выделения малахита и азурита.

Основные минералы руд: пирротин, халькопирит, пентландит и виоларит. В небольшом количестве встречаются пирит, марказит, гидроксиды железа. Реже - рутил, сульфоарсениды, графит, магнетит, самородное золото, гессит, сперрилит и ирарсит. Породообразующие минералы представлены кварцем, полевым шпатом, амфиболом, хлоритом, карбонатом и пироксеном.

Выделены две благороднометалльные ассоциации - ранняя и поздняя. Первая представлена сперрилитом, ирарситом, а также неназванным соединением платины, иридия и теллура. Ранние минералы благородных металлов пространственно и генетически связаны с герсдорфитом, в котором нередко отмечается изоморфная примесь платиноидов. В позднюю ассоциацию входят майченерит, волынскит, гессит, аргентопентландит, самородное золото, а также содержащий палладий теллуровисмутит (рис. 5).

Дукукско-Пеницкая никеленосная зона расположена в северной части Дукукского рудного района. Она приурочена к Шаромскому разлому и протягивается в северо-восточном направлении на 90 км при ширине около 20 км. В пределах зоны находятся Дукукское рудное поле, ряд проявлений и точек минерализации сульфидных медно-никелевых руд, а также вторичные потоки рассеяния никеля и меди. Наиболее перспективно проявление Дукук с сингенетичным сульфидным медно-никелевым оруденением.

Колпаковский потенциально никеленосный район площадью около 700 км² располо- жен в центральной части Камчатского срединного массива. В геологическом строении района выделяются два структурных этажа. Нижний сложен метаморфитами колпаковской и камчатской серий протерозоя, верхний - терригенными и вулканогенно-терригенными породами хозгонской, алисторской и хейванской свит мелового возраста. Магматические образования представлены интрузиями крутогоровского, левоандриановского, алисторского, кольского и лавкинского интрузивных комплексов. Интрузий никеленосного дукукского комплекса на дневной поверхности не обнаружено, но в бассейне р. Колпакова имеются косвенные признаки неэродированных интрузий, которые по своим свойствам соответствуют базитам этого комплекса.

В пределах Колпаковского потенциального рудного района известны пункты медноникелевой минерализации, а также ореолы и потоки рассеяния никеля и меди. Содержания никеля в ореолах, потоках и единичных пробах из рыхлых отложений не превышают 0.02-0.04\%, из коренных - достигают 0.1-0.15\% (Сидоренко и др., 1999).

Составленные плотностные модели Колпаковского района по геофизическим данным позволили выявить местонахождение на глубине аналогов интрузий дукукского комплекса. С небольшими апофизами этих интрузий, достигающими дневной поверхности, может быть связано сульфидное медно-никелевое оруденение, определяющее перспективы Колпаковского потенциально никеленосного района.

Этап миоценовой активизации. В этот этап произошло внедрение интрузий и даек лавкинского гранодиоритового комплекса. Они сложены гранитами, гранодиоритами, кварцевыми диоритами и диоритами. С интрузиями лавкинского комплекса связаны зоны гидротермально измененных пород, геохимические аномалии меди, золота, а также проявления золото-медномолибден-порфировой формации, представленные штокверками или зонами прожилково-вкрапленной золотосульфидной минерализации в гидротермально измененных интрузивных породах. Интрузивные образования лавкинского комплекса прорывают все домиоценовые образования. Радиоизотопные K-Ar определения возраста показали 8 и 19 млн лет (Сляднев, Шаповаленко, 2007). Проявления золото-медно-молибденпорфировой формации этого этапа развиты в пределах двух потенциально рудных узлах - ХимКирганикском и Крутогоровско-Андриановском.

Хим-Кирганикский рудный узел расположен в северо-восточной части КСМ. Площадь узла сложена породами кирганикской свиты мелпалеоценового возраста, прорванными интрузией и дайками лавкинского гранодиоритово- 

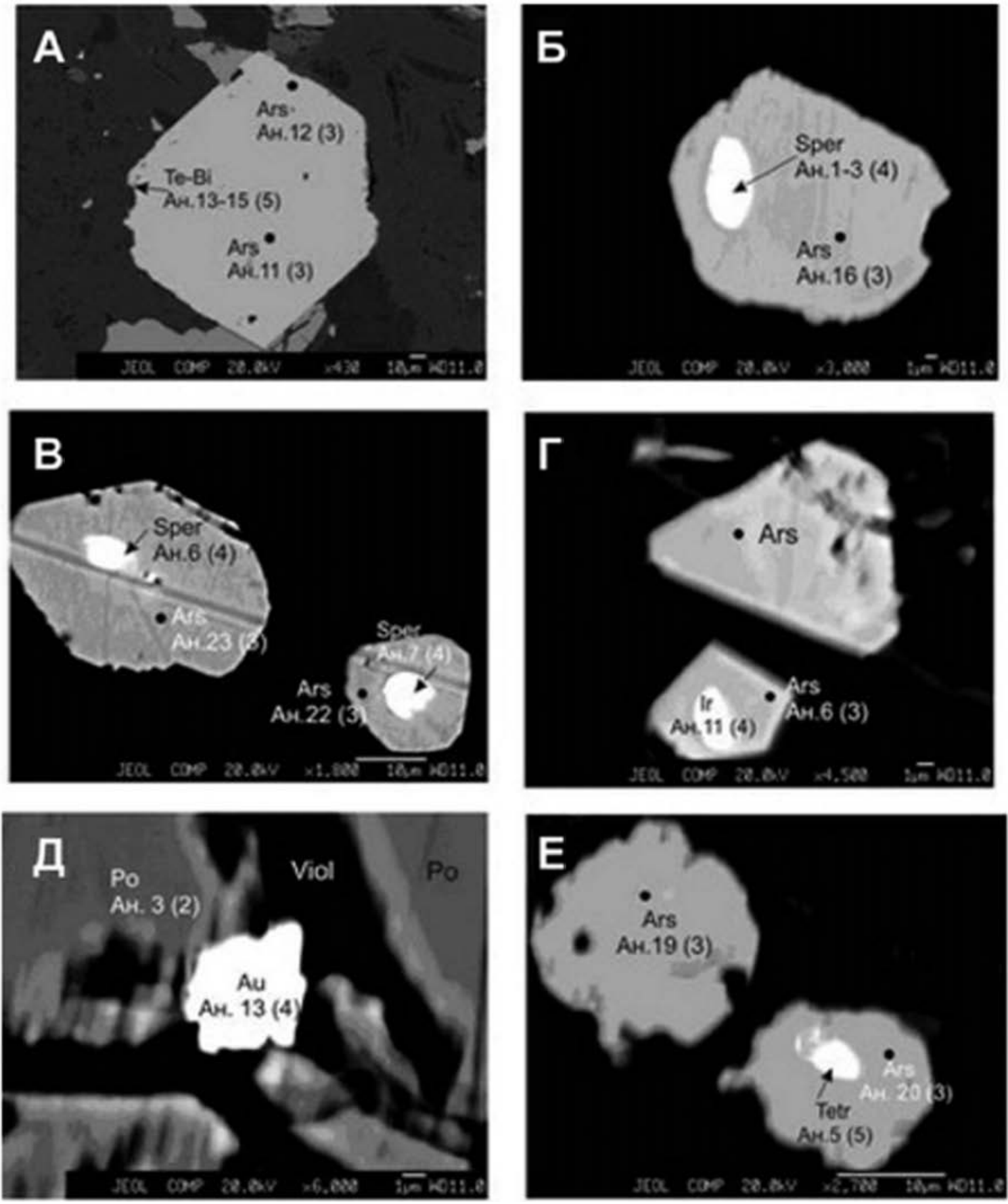

Puc. 5. Редкие минералы проявления Аннабергитовая Щель: A - сульфоарсенид (Ars) с микровключениями теллуро-висмутовых (Те-Вi) минералов; Б - вкрапленник сперрилита (Sper) округлой формы в сульфоарсениде; В - сперрилит в идиоморфных зернах сульфоарсенида; $\Gamma$ - ирарсит (Ir) в сульфоарсениде; Д - самородное золото (Au) в виоларите (Viol); Е - тетрадимит (Tetr) в сульфоарсениде

Fig. 5. Rare minerals of the Annabergitovaya Shchel occurrence: A - sulpharsenide (Ars) with microinclusions of telluro-bismuth (Te-Bi) minerals; Б - round phenocrysts of sperrylite (Sper) in sulpharsenide; B - sperrylite in automorphic sulpharsenide grains; $\Gamma$ - irarsite (Ir) in sulfarsenide; Д - native gold (Au) in violarite (Viol); $\mathrm{E}$ - tetradymite (Tetr) in sulfarsenide

го комплекса миоценового возраста. В пределах узла находятся четыре проявления золото-медномолибден-порфировой формации - Позднее, Хим, Кирганикское и Туманное.

Проявления приурочены к субвулканическим интрузиям или дайкам диорит-порфири- тов, гранодиоритов миоценового возраста, а также к контактам этих интрузий с вмещающими вулканитами ирунейской свиты. Рудоносными являются зоны, залежи или штокверки метасоматитов биотит-пироксен-калишпатового состава, иногда пропилиты с вкрапленным и 
прожилково-вкрапленным оруденением. Coдержания меди меняются от 0.1 до 5.44\%, золота от 0.1 до 20.7 г/т. Прогнозные ресурсы меди составляют сотни тысяч тонн, золота - до 93 т. Наиболее перспективными для проведения дальнейших поисковых и оценочных работ являются проявления Кирганикское, Позднее и Хим.

Крутогоровско-Андриановский узел расположен в северной части КСМ. Его площадь сложена метаморфическими породами протерозоя, прорванными интрузиями лавкинского комплекса миоценового возраста. Центральную часть узла занимают вулканиты хангарского андезидацитового комплекса четвертичного возраста, слагающие вулканическое сооружение Хангар. В пределах узла находятся четыре проявления золото-медно-молибден-порфировой формации: Малахитовое, Квахона, Право-Хейванское и Андриановское.

Вмещающими породами являются субвулканические интрузии гранодиоритов, андезитов и диорит-порфиритов мел-палеоценового и миоценового возраста. Рудные тела представлены штокверками, реже зонами прожилкововкрапленной сульфидной или кварц-сульфидной минерализации. Из рудных минералов отмечаются халькопирит, пирит, молибденит, реже халькозин, ковеллин, борнит, магнетит. Содержание меди меняется от 0.4-0.8\% (проявления Хим и Малахитовое) до $1 \%$, максимальное содержание меди до $5.44 \%$ отмечается в проявлении Позднее. Концентрация молибдена достигает $0.1 \%$ в рудопроявлениях Малахитовое и Право-Хейванское, в остальных ниже. Золото отмечается в количествах от 0.1 до 0.2 , достигая 3.7 (проявление Право-Хейванское), 5.2 (Хим) и 20.7 г/т (Позднее). Наблюдается отчетливая тенденция увеличения концентрации 3олота при высокой медистости руд. Наибольший интерес для постановки дальнейших поисковооценочных работ представляет рудопроявление Малахитовое, прогнозные ресурсы которого составляют: меди - 1874 тыс. т, молибдена - 56 тыс. т и золота -16 т.

\section{ОБСУЖДЕНИЕ РЕЗУЛЬТАТОВ}

Проведенное исследование показало своеобразие металлогении Камчатского массива. Оно заключается в преобладании мезозойскокайнозойских этапов проявления золотого, медно-никелевого и золото-медно-молибденпорфирового типов оруденения. Это значительно отличает КСМ от других срединных массивов Востока России. Так, на расположенном западнее Омолонском срединном массиве известны докембрийские железистые кварциты, палеозойские молибден-медно-порфировые, полиметаллические, золотые, золото-теллуридные и золото-серебряные месторождения и рудопроявления. Для Охотского массива характерна молибденитовая, сульфидно-полиметаллическая, золото-редкометалльная, золото-серебряная и сурьмяно-ртутная минерализация мелового возраста (Сидоров и др., 2008).

\section{ЗАКЛЮЧЕНИЕ}

В пределах Камчатского срединного массива выявлены три этапа отраженной активизации - позднемеловой, эоценовый и миоценовый. В результате первого из них было сформировано золотое оруденение золото-кварцевой и золотосульфидно-кварцевой формации, парагенетически связанное с внедрением гранитоидных интрузий кольского комплекса верхнего мела. Вследствие размыва оруденения этого типа произошло образование россыпей золота. Второй этап характеризовался внедрением в эоцене интрузий, силлов и даек дукукского комплекса. К интрузиям этого комплекса приурочено оруденение сульфидной платиноидно-медно-никелевой формации. В миоцене произошло становление интрузий и даек гранодиоритового лавкинского комплекса третьего этапа активизации. В них часто присутствуют зоны гидротермально измененных пород, вмещающие проявления золотомедно-молибден-порфировой формации.

Камчатский срединный массив перспективен в первую очередь на выявление новых месторождений сульфидной медно-никелевой формации с богатыми рудами. Кроме того, определенный интерес представляют слабо изученные проявления золото-кварцевой, золотосульфидно-кварцевой и золотомедно-молибден-порфировой формации, а также россыпи золота.

\section{ЛИТЕРАТУРА}

Боровцов А. К., Сидоренко В. И., Щенко В. И., Ярыш Г. В., Хасанов Ш. Г. Государственная геологическая карта РФ м-ба 1:200 000. Лист N-57-XX. Объяснит. записка. Москва : МФ ВСЕГЕИ, 2016. $147 \mathrm{c}$.

Боровиов А. К., Ярыши Г. В., Бархатов Ю. В., Щенко В. И., Хасанов Ш. Г. Государственная геологическая карта РФ м-ба 1:200 000. Лист N-57-XXVI. Объяснит. записка. Москва : МФ ВСЕГЕИ, 2013. 181 с.

Виноградов В. И., Григорьев В. С. Rb-Sr возраст пород Срединного выступа Камчатки // ДАН. 1994. T. 339, № 5. С. 645-649.

Карта полезных ископаемых Камчатской области м-ба 1: 500 000. Краткая объяснительная записка / гл. ред. А. Ф. Литвинов, М. Г. Патока, Б. А. Марковский. Санкт-Петербург : ВСЕГЕИ, 1999. 563 с.

Корякско-Камчатский район - новая платиноносная провинция России / Е. Ю. Вильданова, В. П. Зайцев, Л. И. Кравченко. Санкт-Петербург : ВСЕГЕИ, 2002. $383 \mathrm{c}$.

Кунгурова В. Е., Степанов В. А., Трухин Ю. П. Медно-никелевое рудопроявление Аннабергитовая 
Щель Камчатской никеленосной провинции // ГИАБ. 2014. № 52. С. 324-333.

Нгуен Динь Kam. Типы срединных массивов Земли // ДАН СССР. 1983. Т. 269, № 4. С. 905-908.

Некрасов Е. Г. Тектоническая природа КорякскоКамчатского региона и вопросы геодинамики складчатого обрамления севера Тихого океана // Геотектоника. 2003. № 6. С. 53-79. eLibrary ID: 17347988.

Полетаев B. A. Сульфидные платиноидномедно-никелевые месторождения и рудопроявления перидотит-пироксенит-норитовой формации Центральной Камчатки. Платина России. Москва : ЗАО «Геоинформмарк», 1999. Т. 3. Кн. 2. С. 191-199.

Селянгин О. Б. О тектонической позиции никеленосных интрузивов Срединно-Камчатского массива // Вестник КРАУНЦ. Науки о Земле. 2009. № 13. С. 123-138.

Сидоренко В. И., Селиванов М. Т., Лисович В. А. Государственная геологическая карта РФ м-ба 1 : 200 000. Лист N-57-XIV. Объяснит. записка. Москва : МФ ВСЕГЕИ, 1999. 159 с.

Сидоров А. А., Волков А. В., Алексеев В. Ю. О металлогении кратонных террейнов и районов «пологих дислокаций» на Северо-Востоке России // ДАН. 2008. Т. 423, № 6. С. 783-787.

Сидоров М. Д., Степанов В. А. Геофизические поля и никеленосность Камчатского срединного массива // Вестник КРАУНЦ. 2006. № 8. С. 140-150.

Сляднев Б. И., Шаповаленко В. Н. Государственная геологическая карта РФ м-ба 1:1 000 000. Сер.
Корякско-Камчатская. Лист N-57. Объяснит. записка. Санкт-Петербург : ВСЕГЕИ, 2007. 187 с.

Степанов B. А. Золото и ртуть в процессах рудообразования на Камчатке // Известия вузов. Геология и разведка. 2018. № 4. С. 54-60. eLIBRARY ID: 35376888

Степанов В. А., Трухин Ю. П. О возрасте Шанучского медно-никелевого месторождения // ДАН. 2007. T. 417, № 1. C. 84-86.

Степанов В. А., Гвоздев В. И., Трухин Ю. П., Кунгурова B. E. Минералы благородных и редких металлов в рудах Шанучского медно-никелевого месторождения (Камчатка) // Записки РМО. 2010. Ч. 139. Вып. 2. C. 43-58. eLIBRARY ID: 17047026

Трухин Ю. П., Степанов В. А. Сидоров М. Д. Камчатская никеленосная провинция // ДАН. 2008. Т. 418, № 6. C. 802-805.

Трухин Ю. П., Степанов В. А., Сидоров М. Д., Кунгурова В. Е. Шанучское медно-никелевое месторождение: геолого-геофизическая модель, состав и геохимия руд // Руды и металлы. 2009. № 5. С. 7581.

Ханчук А. И. Геология и происхождение Срединнокамчатского кристаллического массива // Тихоокеанская геология. 1983. № 4. С. 45-53.

Щеглов А. Д. Металлогения срединных массивов. Ленинград : Недра, 1971. 148 с.

Яншин А. Л. Проблема Срединных массивов // Бюл. МОИП. Сер. Геол. 1965. Т. 40, № 5. С. 8.

Поступила в редакиию 14.07.2020 г.

Поступила после доработки 09.08.2020 2.

\title{
METALLOGENY OF THE KAMCHATKA MIDDLE MASSIF
}

\author{
V. A. Stepanov, V. Ye. Kungurova, I. A. Koidan \\ Research Geotechnological Center FEB RAS, Petropavlovsk-Kamchatsky
}

\begin{abstract}
The article describes the ore bearance of three stages of reflected activation of the Kamchatka middle massif: Late Cretaceous, Eocene, and Miocene. In the first stage, gold mineralization of the goldquartz and gold-sulfide-quartz formations was formed; in the second - sulfide platinoid-coppernickel; in the third - gold-copper-molybdenum-porphyry. The relationship of gold, sulfide platinoidcopper-nickel and gold-copper-molybdenum-porphyry mineralization with certain igneous rock complexes - (Kola, Dukuk and Lavkin) is shown. The mining of nickel, copper from the Shanuch deposit and gold from placers has been noted.
\end{abstract}

Keywords: metallogeny, reflected activation, the ore formation, deposit, occurrence, placer.

\section{REFERENCES}

Borovtsov, A. K., Sidorenko, V. I., Shchenko, V. I., Yarysh, G. V., Khasanov, Sh. G., 2016. State Geological Map of the Russian Federation. Scale 1: 200 000, Sheet N-57-XX, Explanatory Letter. Moscow, MB VSEGEI [In Russian].

Borovtsov, A. K., Yarysh, G. V., Barkhatov, Yu. V., Shchenko, V. I., Khasanov, Sh. G., 2013. State Geological Map of the Russian Federation. Scale 1: 200 000, Sheet N-57-XXVI, Explanatory Letter. Moscow, MB VSEGEI [In Russian].
Khanchuk, A. I., 1983. Geology and Origin of the Middle-Kamchatka Crystalline Massif, Tikhookeanskaya Geologiya. 4, 45-53 [In Russian].

Koryak-Kamchatka Region - a New PlatinumBearing Province of Russia, 2002. Ye. Yu. Vildanova, V. P. Zaytsev, L. I. Kravchenko. St. Petersburg, VSEGEI [In Russian].

Kungurova, V. E., Stepanov, V. A., Trukhin, Yu. P., 2014. Annabergitovaya Shchel Copper-Nickel Ore Occurrence 
of the Kamchatka Nickel-Bearing Province, GIAB. 52, 324-333 [In Russian].

Map of Mineral Resources of the Kamchatka Region, 1: 500000 Scale, 1999. Brief Explanatory Note, Ch. Ed. A. F. Litvinov, M. G. Patoka, B. A. Markovsky. St. Petersburg, VSEGEI [In Russian].

Nekrasov, E. G., 2003. Tectonics of the Koryak-

Kamchatka Region and the General Geodynamics of the

North Pacific RIM, Geotektonika. 6, 53-79. eLibrary ID: 17347988

Nguyen Dinh Cat, 1983. Types of the Earth Middle Massifs, Doklady Akademiyi Nauk SSSR. 269, 4, 905-908

[In Russian].

Poletaev, V. A., 1999. Sulfide Platinoid-CopperNickel Deposits and Ore Occurrences of the PeridotitePyroxenite-Norite Formation in Central Kamchatka, Platinum of Russia. 3, 2, Moscow, ZAO Geoinformmark, 191-199 [In Russian].

Scheglov, A. D., 1971. Metallogeny of Middle Massifs. Leningrad, Nedra [In Russian].

Selyangin, O. B., 2009. On the Tectonic Position of Nickel-Bearing Intrusions of the Middle-Kamchatka Massif, Bulletin of KRAESC, Earth Sciences. 13, 123-138

[In Russian].

Sidorenko, V. I., Selivanov, M. T., Lisovich, V. A., 1999. State Geological Map of the Russian Federation, Scale 1: 200 000, Sheet N-57-XIV, Explanatory Letter. Moscow, MB VSEGEI [In Russian].

Sidorov, M. D., Stepanov, V. A., 2006. Geophysical Fields and Nickel Bearing of the Kamchatka Middle Massif, Vestnik KRAESC. 8, 140-150 [In Russian].

Sidorov, A. A., Volkov, A. V., Alekseev, V. Yu., 2008. On Metallogeny of Cratonic Terranes and Areas of "Gentle
Dislocations" in the North-East of Russia, Doklady Akademiyi Nauk. 423, 6, 783-787 [In Russian].

Slyadnev, B. I., Shapovalenko, V. N., 2007. State Geological Map of the Russian Federation, Scale 1: 1000 000, Series Koryak-Kamchatka, Sheet N-57, Explanatory Letter. St. Petersburg, VSEGEI [In Russian]. Stepanov, V. A., 2018. Gold and Mercury in the Procisses of Ore Formation in Kamchatka, Proceedings, of Higher Educational Establishments, Geology and Exploration. 4, 54-60. eLIBRARY ID: 35376888 [In Russian].

Stepanov, V. A., Gvozdev, V. I., Trukhin, Yu. P., Kungurova, V. E., 2010. Minerals of Precious and Rare Metals in Ores of the Shanuchskoye Copper-Nickel Deposit (Kamchatka), Zapiski RMO. 139, 2, 43-58. eLIBRARY ID: 17047026 [In Russian].

Stepanov, V.A., Trukhin, Yu. P., 2007. On the Age of the Shanuchsky Copper-Nickel Deposit, Doklady Akademiyi Nauk. 417, 1, 84-86 [In Russian].

Trukhin, Yu. P., Stepanov, V. A. Sidorov, M. D., 2008. Kamchatka Nickel-Bearing Province, Doklady Akademiyi Nauk. 418, 6, 802-805 [In Russian].

Trukhin, Yu. P., Stepanov, V. A., Sidorov, M. D., Kungurova, V. E., 2009. Shanuchskoye Copper-Nickel Deposit: Geological and Geophysical Model, Composition and Geochemistry of Ores, Ores and Metals. 5, 75-81 [In Russian].

Vinogradov, V. I., Grigoriev, V. S., 1994. Rb-Sr Age of Rocks of the Sredinny Uplift of Kamchatka, Doklady Akademiyi Nauk. 339, 5, 645-649 [In Russian].

Yanshin, A. L., 1965. The Problem of Middle Massifs, Bulletin Moscow Society of Naturalists. Geological Series. 40, 5 [In Russian]. 